\title{
Agglomeration mechanism in biomass fluidized bed combustion - Reaction between potassium carbonate and silica sand
}

Anicic, Bozidar; Lin, Weigang; Dam-Johansen, Kim; Wu, Hao

\section{Published in:}

Fuel Processing Technology

Link to article, DOI:

10.1016/j.fuproc.2017.10.005

Publication date:

2018

Document Version

Peer reviewed version

Link back to DTU Orbit

Citation (APA):

Anicic, B., Lin, W., Dam-Johansen, K., \& Wu, H. (2018). Agglomeration mechanism in biomass fluidized bed combustion - Reaction between potassium carbonate and silica sand. Fuel Processing Technology, 173, 182190. https://doi.org/10.1016/j.fuproc.2017.10.005

\section{General rights}

Copyright and moral rights for the publications made accessible in the public portal are retained by the authors and/or other copyright owners and it is a condition of accessing publications that users recognise and abide by the legal requirements associated with these rights.

- Users may download and print one copy of any publication from the public portal for the purpose of private study or research.

- You may not further distribute the material or use it for any profit-making activity or commercial gain

- You may freely distribute the URL identifying the publication in the public portal 


\author{
Bozidar Anicic ${ }^{a, b}$, Weigang Lin ${ }^{a}$, Kim Dam-Johansen ${ }^{a}, H a o ~ W u^{a^{*}}$
}

5

6 a Department of Chemical and Biochemical Engineering, Technical University of Denmark, Søltofts Plads, Building 229, 2800 Kongens Lyngby, Denmark

8 bSino-Danish Center for Education and Research, 380 Huaibeizhuang, Huairou district, Beijing,

10 * Corresponding author: Tel: +45 452529 27, Fax: +45 4588 22 58, E-mail: haw@kt.dtu.dk 


\section{ABSTRACT}

2 Agglomeration is one of the operational problems in fluidized bed combustion of biomass, which 3 is caused by interaction between bed materials (e.g. silica sand) and the biomass ash with a high

4 content of potassium species. However, the contribution of different potassium species to

5 agglomeration is not fully understood yet. In the present work, the reaction between $\mathrm{K}_{2} \mathrm{CO}_{3}$ and

6 silica sand has been studied extensively by thermogravimetric analysis. The reacted samples

7 were analyzed by SEM-EDX to reveal the reaction mechanism. The results indicated that the

8 reaction occurs in a solid-solid phase already at temperatures around $700{ }^{\circ} \mathrm{C}$. The reaction rate

9 increases with increasing temperature, but decreases with an increase of $\mathrm{CO}_{2}$ partial pressure.

10 Using smaller particle size and well mixed solid reactants results in an increased reaction rate. It

11 is observed that the reaction initiates in the contact area between $\mathrm{K}_{2} \mathrm{CO}_{3}$ and silica sand, forming

12 a thin product layer. The layer acted as a reactive media further reacting with $\mathrm{K}_{2} \mathrm{CO}_{3}$ and silica

13 sand. The results provide a basis for understanding of potassium induced agglomeration process

14 in fluidized bed biomass combustion.

15 Keywords: fluidized bed combustion; biomass; agglomeration; reaction mechanism; potassium

16 carbonate; silica sand. 


\section{INTRODUCTION}

2 Fluidized bed combustion is a promising technology to utilize biomass for heat and power production [1]. The technology offers a good fuel flexibility and a high combustion efficiency [2-4]. However, a main challenge associated with fluidized bed combustion of biomass is agglomeration, which can influence bed hydrodynamics, change fluidization regime, and eventually result in defluidization, causing unscheduled shutdown of the plant [5-7]. In biomass combustion, agglomeration is to a large extent caused by the interactions between the bed materials (e.g. silica sand) and the potassium species present in biomass [5,8-10].

During combustion, the potassium in the biomass may be released and transformed to gaseous/aerosol phase (e.g. as $\mathrm{KCl}, \mathrm{K}_{2} \mathrm{SO}_{4}, \mathrm{~K}_{2} \mathrm{CO}_{3}$ ) or retained in ash. Knudsen el al. revealed that a fraction of 20 to $45 \%$ of the potassium in annual biomass is released to the gas phase via $\mathrm{KCl}$ vaporization during combustion below $800{ }^{\circ} \mathrm{C}$ [11]. The presence of $\mathrm{KCl}$ in biomass ash was confirmed by several studies through XRD analysis [12-15]. At temperatures higher than $850{ }^{\circ} \mathrm{C}$, the potassium release may be associated with decomposition of other potassium salts such as $\mathrm{K}_{2} \mathrm{CO}_{3}$ and $\mathrm{K}_{2} \mathrm{SO}_{4}$ [11]. $\mathrm{K}_{2} \mathrm{SO}_{4}$ has been found in the ashes obtained from straw and wood combustion [16,17]. The formation of $\mathrm{K}_{2} \mathrm{CO}_{3}$ during biomass combustion has been suggested by several thermodynamic studies $[15,18,19]$, and it has been detected in the fly ash obtained from a full-scale pulverized wood combustion boiler [20], and in the ash obtained from a groundnut shell combustion below $650{ }^{\circ} \mathrm{C}$ [12]. In addition, Zhao et al. found that a significant amount of the $\mathrm{K}_{2} \mathrm{CO}_{3}$ can be present in the char from a fast pyrolysis of rice husk in a temperature range of $500-900{ }^{\circ} \mathrm{C}$, based on the measured water soluble potassium and the anions $\left(\mathrm{SO}_{4}{ }^{2-}, \mathrm{PO}_{3}{ }^{3-}, \mathrm{HCO}^{3-}\right)$ [21]. Recently, Chen et al. reported the formation of $\mathrm{K}_{2} \mathrm{CO}_{3}$ from char bonded potassium during pyrolysis of $\mathrm{KCl}$ loaded cellulose samples [22]. The potassium retained in the residual ash of a biomass is mainly present as potassium silicates $[23,24]$.

The potassium species formed in fluidized bed biomass combustion may interact in different ways with the bed materials (typically silica sand). Grimm et al. suggested that the agglomeration process can be initiated by the formation of a coating layer via reactions between gaseous or liquid K-compound and silica sand bed material [2]. Scala et al. suggested that a nonmolten or partially molten ash particles can be deposited at silica sand surface [9]. Subsequently, the potassium retained in ash (e.g. as K-silicates or $\mathrm{K}_{2} \mathrm{CO}_{3} / \mathrm{K}_{2} \mathrm{SO}_{4}$ in aerosol form) can interact with the sand forming various potassium silicates [9]. Moreover, some of the potassium species may condensate on the bed material surface, due to the difference between local combustion and an average bed temperatures [5]. Figure 1 summarizes the possible interactions between potassium species and bed material during biomass combustion.

Recently, Gatternig and Karl investigated the different agglomeration mechanisms relevant for

36 biomass combustion, by performing two-stage experiments [5]. They concluded that the 37 agglomeration is mainly caused by the interactions between the adhered solid ash particles and 
the silica sand; resulting in formation of a multi-coating layer responsible for particles binding.

2 The binding neck may consist of the molten ash particles, which was usually observed for

3 herbaceous biomass. However, the gas-solid reaction and the condensation of potassium did not

4 contribute to agglomeration in their experiments [5].

5 The interactions of different potassium species and silica sand have been studied under fluidized 6 bed and fixed bed conditions to understand their impacts on agglomeration [25-27]. Sevonius et 7 al. studied the agglomeration in a laboratory scale fluidized bed, with the silica sand as a bed 8 material, by adding model salts $\left(\mathrm{KCl}, \mathrm{K}_{2} \mathrm{CO}_{3}, \mathrm{~K}_{2} \mathrm{SO}_{4}\right)$ in a temperature range of $750-900{ }^{\circ} \mathrm{C}$ 9 [25]. A defluidization occurred in the case of $\mathrm{KCl}$ and $\mathrm{K}_{2} \mathrm{CO}_{3}$ addition, while no bed 10 agglomeration was observed in the case of $\mathrm{K}_{2} \mathrm{SO}_{4}$ addition. $\mathrm{KCl}$ did not react with the silica sand 11 but acted as a glue agent to bind bed particles, while $\mathrm{K}_{2} \mathrm{CO}_{3}$ reacted with silica sand to form a 12 molten phase responsible for the bed agglomeration [25]. Narayan et al. performed similar 13 experiments in a lab scale fluidized bed, where model salts $\left(\mathrm{KCl}\right.$ and $\left.\mathrm{K}_{2} \mathrm{CO}_{3}\right)$ were added to the 14 silica sand in order to identify the defluidization temperature [26]. The $\mathrm{KCl}$ addition caused 15 defluidization in the temperature range 756-765 ${ }^{\circ} \mathrm{C}$, while the $\mathrm{K}_{2} \mathrm{CO}_{3}$ addition caused 16 defluidization between $728-737^{\circ} \mathrm{C}$. SEM-EDX analysis revealed that $\mathrm{KCl}$ did not react with the 17 silica sand, while $\mathrm{K}_{2} \mathrm{CO}_{3}$ reacted with the sand, forming high viscous potassium silicates [26]. $18 \mathrm{Ma}$ et al. investigated the interaction between $\mathrm{K}_{2} \mathrm{SO}_{4}$ and $\mathrm{SiO}_{2}$ under different atmospheres (air, steam and $\mathrm{H}_{2}$ ) below $900{ }^{\circ} \mathrm{C}$ at fixed bed conditions [27]. Similar to Sevonius et al. work [25], no interaction between $\mathrm{K}_{2} \mathrm{SO}_{4}$ and $\mathrm{SiO}_{2}$ in air and steam atmosphere was observed. However, the formation of a potassium silicate was observed in $\mathrm{H}_{2}$ atmosphere below $900{ }^{\circ} \mathrm{C}$, which was attributed to reaction between $\mathrm{K}_{2} \mathrm{SO}_{4}$ and silica sand under such conditions [27].

Although it is known that the reaction between $\mathrm{K}_{2} \mathrm{CO}_{3}$ and silica sand can induce agglomeration, the detailed reaction mechanism and the impact of reaction parameters are not well understood [25-27]. To our knowledge, only Arvelakis et al. briefly studied the reaction between $\mathrm{K}_{2} \mathrm{CO}_{3}$ and silica sand in a TGA [28]. A significant mass loss was observed for a mixture of $\mathrm{K}_{2} \mathrm{CO}_{3}$ and silica sand heated from $700{ }^{\circ} \mathrm{C}$ to $1100{ }^{\circ} \mathrm{C}$. On the other hand, pure $\mathrm{K}_{2} \mathrm{CO}_{3}$ decomposition under neutral atmosphere primarily started at approximately $1050{ }^{\circ} \mathrm{C}$ [28], implying that the significant mass loss measured below $1050{ }^{\circ} \mathrm{C}$ is a result of the reaction between $\mathrm{K}_{2} \mathrm{CO}_{3}$ and silica sand.

In this work, a systematic investigation on the reaction between $\mathrm{K}_{2} \mathrm{CO}_{3}$ and the silica sand was performed in a TGA. The influence of the important parameters, such as temperature, $\mathrm{CO}_{2}$ partial pressure, the mixing of solid particles, and particle size was examined. SEM-EDX analyses of the reaction products, and thermodynamic calculations of the reaction systems, were carried out to understand the reaction mechanism. 


\section{EXPERIMENTAL}

\subsection{Materials}

Analytic pure potassium carbonate (CAS 584-08-7, 99.9\%) with two particle size ranges, i.e. a size range of 2.58 to $224 \mu \mathrm{m}$ (a mean diameter of $18 \mu \mathrm{m}$, hereafter denoted as powder $\mathrm{K}_{2} \mathrm{CO}_{3}$ ) and a size range of 146 to $489 \mu \mathrm{m}$ (a mean diameter of $285 \mu \mathrm{m}$, hereafter denoted as coarse $\mathrm{K}_{2} \mathrm{CO}_{3}$ ), were used. Moreover, potassium silicate, $\mathrm{K}_{2} \mathrm{O} \cdot \mathrm{nSiO}_{2}$ ( $\mathrm{n}=4$, corresponding to $\mathrm{K}_{2} \mathrm{Si}_{4} \mathrm{O}_{9}$ ) was melted at $850{ }^{\circ} \mathrm{C}$, and grinded to a narrow size between 180 to $355 \mu \mathrm{m}$. The silica sand particles used have a size between 255 to $483 \mu \mathrm{m}$ (a mean diameter of $385 \mu \mathrm{m}$ ), which is within the size range commonly used in fluidized bed boilers [29]. The sand was pretreated at $800{ }^{\circ} \mathrm{C}$ under oxidizing conditions for $2 \mathrm{~h}$ in order to remove potential organic impurities.

The melting temperatures of the $\mathrm{K}_{2} \mathrm{CO}_{3}$ and $\mathrm{SiO}_{2}$ are $891{ }^{\circ} \mathrm{C}$ and $1710{ }^{\circ} \mathrm{C}$, respectively [30]. Any reaction between $\mathrm{K}_{2} \mathrm{CO}_{3}$ and $\mathrm{SiO}_{2}$ occurring below the melting points of both reactants indicates that the reaction is initiated in a solid-solid state [28]. Consequentially, mixing of the reactants may be an important parameter. Thus, three different mixing modes were used in the experiments: well-mixed, two layers (segregated layers of salt and sand with the same surface area), localized two layers (a layer of salt localized at the middle of the sand surface). The wellmixed samples were prepared by manual mixing of the particles for 10 mins in a cylindrical TGA crucible with a diameter of $16 \mathrm{~mm}$ and a height of $20 \mathrm{~mm}$. The two layers samples were prepared by placing the sand at the bottom of the crucible, while the $\mathrm{K}_{2} \mathrm{CO}_{3}$ was placed above it to completely cover the upper sand surface. The procedure was similar for preparing the localized two layers samples, but in this case the $\mathrm{K}_{2} \mathrm{CO}_{3}$ was localized at the middle of the sand layer.

\subsection{Experimental setup}

The experiments were carried out in a high-heating rate thermogravimetric analyzer (TGA, Netzsch STA 449 F1 Jupiter), which is capable to heat up the sample up to a maximal heating rate of $1000 \mathrm{~K} / \mathrm{min}$. The uncertainty of the TGA is $\pm 0.001 \mathrm{mg}$, which is several orders of magnitude lower that the mass of samples placed (approximately $0.7 \mathrm{~g}$ in each run) in the TGA, indicating that the instrumental error is negligible. Besides that, the results of the repeatability tests showed that the average deviation of the experiments was less than $2 \%$ (provided in the Supporting Information).

The same temperature program was used for all experiments: the sample was firstly heated to $150{ }^{\circ} \mathrm{C}$ and kept for 1 hour to remove moisture. Afterwards, the sample was heated to a final temperature (between 700 and $850{ }^{\circ} \mathrm{C}$ ) at a heating rate of $500 \mathrm{~K} / \mathrm{min}$ and kept for 4 hours. The heating rate was chosen to mimic the rapid heating of particles in a fluidized bed. However, due to the high heating rate, the experiments are to a large extent carried out under isothermal conditions. Thus, for presenting the results, the initial time $(t=0 \mathrm{~s})$ is chosen to be the time when the final temperature was reached. A gas flow rate of $50 \mathrm{ml} / \mathrm{min}$ was used for all experiments. 
1 The experiments were carried out under pure $\mathrm{N}_{2}$, pure $\mathrm{CO}_{2}$, and a mixture of $50 \% \mathrm{CO}_{2}$ and $50 \%$

$2 \mathrm{~N}_{2}$ conditions. Considering the typical flue gas composition in a fluidized bed boiler, it would be 3 interesting to study the reaction under $\mathrm{H}_{2} \mathrm{O}$ atmosphere. However, our TGA cannot be operated 4 under $\mathrm{H}_{2} \mathrm{O}$ atmosphere. Based on thermodynamic equilibrium calculations, the difference of 5 studying the reaction in $\mathrm{N}_{2}$ atmosphere and in air atmosphere is negligible. Thus, for the 6 convenience of operating the TGA, $\mathrm{N}_{2}$ is used instead of air.

\section{$7 \quad 2.3$ Analytical methods}

8 The solid samples obtained from the experiments were analyzed by using a Scanning Electron 9 Microscopy with Energy dispersive X-ray (SEM-EDX) analysis (JEOL JSM-5910). Some of the 10 samples were imbedded in an epoxy resin and gradually polished using a fine emery paper and 11 an ethanol solution to reveal the cross section of the agglomerated silica sand grains.

12 Additionally, XRD analysis was performed to identify the products of reaction using a Huber 13 diffractometer with a characteristic $\mathrm{Cu} \mathrm{K} \alpha$ radiation and operation conditions of $40 \mathrm{kV}$ and 40 $14 \mathrm{~mA}$. The exposure time was 30 mins.

\section{$15 \quad 2.4$ Thermodynamic equilibrium calculations}

16 Thermodynamic equilibrium calculations can provide information about the thermodynamically 17 favored products under different operating conditions. In the present work, equilibrium 18 calculations of the reaction systems were performed in the FACTSAGE 7.0 software. The 19 FToxid and the FactPS databases were chosen for the simulation. SlagA model for liquid phase 20 calculation was chosen, since it gave the best fitting between the calculated results of the 21 investigated system and experimentally results reported for a similar $\mathrm{K}_{2} \mathrm{O}-\mathrm{SiO}_{2}$ system [30].

22 The calculations were done for different $\mathrm{SiO}_{2}: \mathrm{K}_{2} \mathrm{CO}_{3}$ molar ratios under pure $\mathrm{N}_{2}$ and pure $\mathrm{CO}_{2}$ 23 atmospheres. Calculations were performed in the temperature range 500 and $1500{ }^{\circ} \mathrm{C}$, but the 24 range between 700 and $900{ }^{\circ} \mathrm{C}$ is most relevant for the present study. The most common $25 \mathrm{SiO}_{2}: \mathrm{K}_{2} \mathrm{CO}_{3}$ molar ratio used in experiments was 1:0.013 (equal to 100:3 mass ratio), 26 corresponding to the overall (global) ratio. Moreover, since both reactants were present in the 27 solid state, it is expected that the local concentration differs from the global concentration. Thus, 28 a range of $\mathrm{SiO}_{2}: \mathrm{K}_{2} \mathrm{CO}_{3}$ molar ratios, from 1:0.013 to 1:1, were used in equilibrium calculations. $291 \mathrm{~mol}$ of $\mathrm{SiO}_{2}$ was used in all calculations and the amount of $\mathrm{K}_{2} \mathrm{CO}_{3}$ was changing in order to 30 obtain specified ratios. The amount of bulk gas was in large excess and it was set to 100 moles 31 for all calculations. Preliminary calculation showed that when in large excess, the exact amount 32 of bulk gas has no impact on the results of equilibrium calculations. 


\section{RESULTS AND DISCUSSION}

\subsection{Equilibrium distribution of potassium species}

3

The distributions of potassium species predicted by thermodynamic equilibrium calculations are shown in Figure 2. Moreover, the calculation results for the pure $\mathrm{K}_{2} \mathrm{CO}_{3}$ in $\mathrm{CO}_{2}$ and $\mathrm{N}_{2}$ atmosphere are given as supporting material.

Thermodynamic equilibrium calculations indicated that at least three different potassium silicates can be formed through the following global reactions:

$$
n \mathrm{SiO}_{2}(s)+\mathrm{K}_{2} \mathrm{CO}_{3}(s)=\mathrm{K}_{2} \mathrm{O} \cdot n \mathrm{SiO}_{2}(s, l)+\mathrm{CO}_{2} \quad n=1,2,4
$$

9 The results show that the formation of different potassium silicates $\left(\mathrm{K}_{2} \mathrm{SiO}_{3}, \mathrm{~K}_{2} \mathrm{Si}_{2} \mathrm{O}_{5}\right.$ and $10 \mathrm{~K}_{2} \mathrm{Si}_{4} \mathrm{O}_{9}$ ) is already thermodynamically favorable at $600^{\circ} \mathrm{C}$. At high temperatures, these 11 potassium silicates all convert to a molten phase slag.

12 The formation of the different potassium silicates depends on the molar ratios of the reactants 13 and the gas atmosphere. For high $\mathrm{SiO}_{2}: \mathrm{K}_{2} \mathrm{CO}_{3}$ molar ratios (1:0.25 or above), the formation of $14 \mathrm{~K}_{2} \mathrm{Si}_{4} \mathrm{O}_{9}$ is favorable, and it converts to a molten slag phase at approximately $770{ }^{\circ} \mathrm{C}$, which is in 15 agreement with the experimentally reported formation of liquid phase for $\mathrm{SiO}_{2}: \mathrm{K}_{2} \mathrm{O}$ systems 16 [30]. For a $\mathrm{SiO}_{2}: \mathrm{K}_{2} \mathrm{CO}_{3}$ molar ratio of 1:0.33, both $\mathrm{K}_{2} \mathrm{Si}_{4} \mathrm{O}_{9}$ and $\mathrm{K}_{2} \mathrm{Si}_{4} \mathrm{O}_{5}$ present at low 17 temperatures, and they convert to a molten slag phase at approximately $750{ }^{\circ} \mathrm{C}$. For $\mathrm{SiO}_{2}: \mathrm{K}_{2} \mathrm{CO}_{3}$ 18 molar ratios above 1:0.33, the impacts of the $\mathrm{N}_{2}$ and $\mathrm{CO}_{2}$ atmospheres on the equilibrium 19 distribution of potassium species are generally negligible.

20 The impact of the gas atmospheres is significant when the $\mathrm{SiO}_{2}: \mathrm{K}_{2} \mathrm{CO}_{3}$ ratio becomes 1:1. In

21 pure $\mathrm{N}_{2}$ atmosphere, the solid phase $\mathrm{K}_{2} \mathrm{SiO}_{3}$ is the only thermodynamically stable species in the temperature range of $700-900{ }^{\circ} \mathrm{C}$. In $\mathrm{CO}_{2}$ atmosphere, both $\mathrm{K}_{2} \mathrm{Si}_{2} \mathrm{O}_{5}$ and $\mathrm{K}_{2} \mathrm{CO}_{3}$ exist at temperatures below $840{ }^{\circ} \mathrm{C}$. Above this temperature, the $\mathrm{K}_{2} \mathrm{Si}_{2} \mathrm{O}_{5}$ and a part of $\mathrm{K}_{2} \mathrm{CO}_{3}$ convert to 24 a molten slag phase. These results indicate that $\mathrm{K}_{2} \mathrm{CO}_{3}$ conversion is hindered in presence of $25 \mathrm{CO}_{2}$, probably due to the fact that the equilibrium of reaction (1) is shifted to left due to the La Chatelier's principle. Consequentially, as the $\mathrm{K}_{2} \mathrm{CO}_{3}$ amount is increasing the formation of $\mathrm{K}_{2} \mathrm{SiO}_{5}$ is more favorable compared to $\mathrm{K}_{2} \mathrm{SiO}_{3}$; meaning that some $\mathrm{K}_{2} \mathrm{CO}_{3}$ remains unconverted.

\subsection{TGA results}

Aforementioned reaction (1) indicates that conversion of $\mathrm{K}_{2} \mathrm{CO}_{3}$ can be monitored by the mass loss caused by the release of $\mathrm{CO}_{2}$. Since thermal decomposition of the $\mathrm{K}_{2} \mathrm{CO}_{3}$ is significant only above $1050{ }^{\circ} \mathrm{C}$, all the mass loss below this temperature was attributed to the $\mathrm{CO}_{2}$ release, and the $\mathrm{K}_{2} \mathrm{CO}_{3}$ conversion can be calculated accordingly.

\section{$33 \quad 3.2 .1$ Influence of reaction temperature}

34 The conversions of powder $\mathrm{K}_{2} \mathrm{CO}_{3}$ under $\mathrm{N}_{2}$ atmosphere, with a $\mathrm{SiO}_{2}: \mathrm{K}_{2} \mathrm{CO}_{3}$ mole ratio of 35 1:0.013, are plotted at Figure 3. The results show that the reaction rate increased with increasing 36 temperature. The reactants were partially converted before the system reached isothermal 
condition. The conversion of $\mathrm{K}_{2} \mathrm{CO}_{3}$ in the heating-up stage was increased with increasing reaction temperature.

At temperatures above $750{ }^{\circ} \mathrm{C}, \mathrm{K}_{2} \mathrm{CO}_{3}$ can be completely converted. However, at $700{ }^{\circ} \mathrm{C}$, the conversion was only approximately 0.8 with a reaction time of $4 \mathrm{~h}$. Considering the typical operation temperatures $\left(800-850{ }^{\circ} \mathrm{C}\right)$ of a fluidized bed boiler and the long residence time of bed particles, the results imply that the reaction between $\mathrm{K}_{2} \mathrm{CO}_{3}$ and silica sand can occur to a considerable degree, if the $\mathrm{K}_{2} \mathrm{CO}_{3}$ and silica sand particles are in close contact.

8 The performed thermodynamical calculations revealed that formation of melt phase is possible

9 above $750{ }^{\circ} \mathrm{C}$. Consequentially, above $750{ }^{\circ} \mathrm{C}$, the overall reaction mechanism can be influenced 10 by the change in physical properties of the formed products. That can provide an explanation 11 why the complete conversion was achieved relatively fast above $750{ }^{\circ} \mathrm{C}$, compared to the $700{ }^{\circ} \mathrm{C}$ 12 where only 0.8 conversion was reached.

\section{$13 \quad$ 3.2.2 Impact of particle size of $\mathrm{K}_{2} \mathrm{CO}_{3}$}

14 Figure 4 illustrates the impact of $\mathrm{K}_{2} \mathrm{CO}_{3}$ particle size (coarse and powder) at two different 15 temperatures $\left(750{ }^{\circ} \mathrm{C}\right.$ and $800{ }^{\circ} \mathrm{C}$ ), with well-mixed $\mathrm{SiO}_{2}: \mathrm{K}_{2} \mathrm{CO}_{3}$ (mole ratio 1:0.013) samples in

16 the $\mathrm{N}_{2}$ atmosphere. The results indicate that the $\mathrm{K}_{2} \mathrm{CO}_{3}$ particle size significantly influenced the 17 initial reaction stages. For the powder $\mathrm{K}_{2} \mathrm{CO}_{3}$ particles, a complete conversion was achieved at 18 both temperatures. However, the coarse $\mathrm{K}_{2} \mathrm{CO}_{3}$ particles only reached a stable conversion around 190.8 and 0.9 , respectively, at $750{ }^{\circ} \mathrm{C}$ and $800{ }^{\circ} \mathrm{C}$.

\subsubsection{Influence of $\mathrm{CO}_{2}$ partial pressure}

The influence of the gas environment was evaluated by performing experiments under pure $\mathrm{N}_{2}$, pure $\mathrm{CO}_{2}$ and a mixture of $50 \% \mathrm{~N}_{2}$ and $50 \% \mathrm{CO}_{2}$. All experiments were performed at $800{ }^{\circ} \mathrm{C}$, using well-mixed $\mathrm{SiO}_{2}$ and powder $\mathrm{K}_{2} \mathrm{CO}_{3}$ with a mole ratio of 1:0.013. The obtained results are plotted at Figure 5. It is shown that the presence of $\mathrm{CO}_{2}$ strongly inhibited the reaction, especially at the initial stage. However, the difference between $50 \% \mathrm{CO}_{2}$ and $100 \% \mathrm{CO}_{2}$ was insignificant.

Thermodynamic calculations revealed that the impact of atmosphere is significant with low $\mathrm{SiO}_{2}: \mathrm{K}_{2} \mathrm{CO}_{3}$ molar ratio, where the conversion of $\mathrm{K}_{2} \mathrm{CO}_{3}$ is less favorable in the presence of $\mathrm{CO}_{2}$. We believe the impact of thermodynamics is dominant in our case. However, the presence of $\mathrm{CO}_{2}$ may also influence $\mathrm{CO}_{2}$ desorption from the reaction surface, which was observed in the sodium carbonate/silica sand system [31,32].

\section{$31 \quad 3.2 .4$ Impact of sand to $\mathrm{K}_{2} \mathrm{CO}_{3}$ mole ratio}

32 Figure 6 shows the impact of mole ratios, for the well-mixed $\mathrm{SiO}_{2}$ and powder $\mathrm{K}_{2} \mathrm{CO}_{3}$ samples at $800^{\circ} \mathrm{C}$ and the $\mathrm{N}_{2}$ atmosphere. A minor effect of the different $\mathrm{K}_{2} \mathrm{CO}_{3}$ content can be observed at

34 the initial reaction stage, showing a slightly higher conversion for a lower content of $\mathrm{K}_{2} \mathrm{CO}_{3}$. The difference became negligible after the conversion reached approximately 0.95 . Overall, all curves were close to each other, implying an insignificant impact of varying $\mathrm{SiO}_{2}: \mathrm{K}_{2} \mathrm{CO}_{3}$ molar

37 ratio from 1:0.009 to 1:0.022. 


\subsubsection{Impact of mixing}

2 Figure 7 illustrates the effect of mixing on the $\mathrm{K}_{2} \mathrm{CO}_{3}$ conversion, for $\mathrm{SiO}_{2}$ and powder $\mathrm{K}_{2} \mathrm{CO}_{3}$ 3 with a mole ratio of 1:0.013 under $\mathrm{N}_{2}$ atmosphere, $800^{\circ} \mathrm{C}$. Initially, the conversions of the two 4 layers and the localized two layers samples were significantly lower compared to the well5 mixture sample. The two-layer sample eventually reached an almost complete conversion after a residence time of $4 \mathrm{~h}$. On the other hand, the final conversion of $\mathrm{K}_{2} \mathrm{CO}_{3}$, in the localized two layers sample, was only about 0.3 .

\subsubsection{Comparison of fused glass and silica sand}

Figure 8 compares the $\mathrm{K}_{2} \mathrm{CO}_{3}$ conversion with a fused glass and the silica sand. Powder $\mathrm{K}_{2} \mathrm{CO}_{3}$ was used in both experiments, and it was localized at the middle of the sand/glass surface (localized two layers). The fused glass was used in order to investigate the impact of the $\mathrm{SiO}_{2}$ structure on the overall reaction rate. The silica sand has a crystalline structure, while the fused glass is in amorphous phase.

14 The $\mathrm{K}_{2} \mathrm{CO}_{3}$ conversion profiles were similar to each other. The initial conversion (up to about 15 0.15) was almost the same for the two cases. Then a noticeable change in the $\mathrm{K}_{2} \mathrm{CO}_{3}$ conversion 16 rate occurred for both samples, with the fused glass having a slight higher reaction rate. The 17 small difference between the fused glass and silica sand might be associated to the difference in 18 surface smoothness.

\subsubsection{Reaction between $\mathrm{K}$-silicate and $\mathrm{K}_{2} \mathrm{CO}_{3}$}

Figure 9 compares the $\mathrm{K}_{2} \mathrm{CO}_{3}$ conversions with potassium silicate $\left(\mathrm{K}_{2} \mathrm{Si}_{4} \mathrm{O}_{9}\right)$ and silica sand. Powder $\mathrm{K}_{2} \mathrm{CO}_{3}$ was used in both experiments, with a reaction temperature of $800{ }^{\circ} \mathrm{C}$ in $\mathrm{N}_{2}$ atmosphere. The results indicated that the reaction rate was similar for silica sand and the potassium silicate. At high conversion degrees, the reaction rate was slightly lower for potassium silicate. Since $\mathrm{K}_{2} \mathrm{Si}_{4} \mathrm{O}_{9}$ is a possible product from the reaction of silica sand and potassium carbonate, the experiments indicate that the formed intermediate potassium silicate product may further react with the potassium carbonate forming different mixtures of potassium silicates.

\subsection{SEM-EDX analyses}

SEM-EDX analyses of the reaction products were performed in order to understand the reaction mechanism. Figure 10 represents a grain from the two layers mixture under the $\mathrm{CO}_{2}$ atmosphere with a $\mathrm{K}_{2} \mathrm{CO}_{3}$ conversion degree of 0.22. Spot 1 characterizes the unreacted $\mathrm{K}_{2} \mathrm{CO}_{3}$, while Spot 3 is the unreacted silica sand surface. Spot 2 represents a layer of produced potassium silicate covering the silica sand surface. The smooth surface implies that the potassium silicate is melted under the experimental temperature $\left(800^{\circ} \mathrm{C}\right)$. Besides, Figure 10 indicates that the reaction can proceed away from the initial contact points between $\mathrm{K}_{2} \mathrm{CO}_{3}$ and the silica sand, since the formed potassium silicate had invaded the unreacted silica surface. However, at the current conditions, the extent of invasion was limited, since only a part of the sand surface was covered by the 37 product layer. 
The observations from Figure 10 lead to a hypothesis that formation of a product coating layer around the sand particle is possible at high conversion degrees and sufficient initial contact areas. The hypothesis is supported by Figure 11, showing that the sand surface is completely covered by a product layer consisting of potassium silicate.

Reacted samples with different $\mathrm{K}_{2} \mathrm{CO}_{3}$ conversion degrees $(0.15 / 0.55 / 0.99)$ were imbedded in an epoxy resign and polished in order to obtain a cross-sectional view of the agglomerated grains. Figure 12 represents the cross-section SEM images of these samples together with an elemental analysis along the lines, as well as the elemental compositions of selected points (e.g. A1). The elemental analysis along the lines provided the intensity of the EDX emission, showing qualitatively the relative distribution of the elements.

11 Sample A shows the initial stage of the reaction. Spot A1 represents the unreacted potassium carbonate, and Spot A2 represents an initial product layer with a Si:K molar ratio of approximately 1 . However, the formed product layer is more heterogeneous compared to the layers in Sample B and Sample C.

15 In Sample B and Sample C, the product layers are quite homogeneous, with more or less constant Si:K molar ratios. The ratio is approximately 2.2 and 2.5, respectively, for Sample B and Sample C, indicating that the product layer consists of a mixture of $\mathrm{K}_{2} \mathrm{Si}_{4} \mathrm{O}_{9}$ and $\mathrm{SiO}_{2}$. It should be pointed out that no unreacted potassium carbonate was observed in the Sample 2 for this particular grain, meaning that its local concentration was relatively low and it was fully converted under the operating conditions.

21 The obtained results are similar as SEM-EDX analysis of agglomerated samples from straw combustion in a lab scale fluidized bed [8]. Lin et al. reported the formation of a continuous product layer covering silica sand surface and acting as a binder of grains. They observed a steep potassium concentration profile at the interphase between the layer and the grain, and concluded that the formation of the layer was main reason for agglomeration [8].

Beside the described SEM-EDX analyses, XRD analysis was also performed to identify the reaction products. The only crystalline phase detected was $\mathrm{SiO}_{2}$, indicating that all of the products were present in amorphous form. The results of XRD analysis are given as supporting material.

\section{$30 \quad 3.4$ Plausible reaction mechanism}

A reaction mechanism, which is proposed based on the experimental results and thermodynamic calculations, is schematically presented in Figure 13. The reaction between $\mathrm{K}_{2} \mathrm{CO}_{3}$ and the silica sand starts at the contact area between the reactants. Initial stage of the reaction depends on the contact areas between reactants, and it results in a relatively homogeneous molten layer of potassium silicates with a comparative low $\mathrm{Si} K \mathrm{~K}$ ratio (e.g. a mixture of $\mathrm{K}_{2} \mathrm{Si}_{4} \mathrm{O}_{9}$ and $\mathrm{K}_{2} \mathrm{Si}_{2} \mathrm{O}_{5}$ ). 
1 resulting in an expanding homogeneous product layer with increasing $\mathrm{Si}: \mathrm{K}$ ratios (e.g. a mixture

2 of $\mathrm{K}_{2} \mathrm{Si}_{4} \mathrm{O}_{9}$ and $\mathrm{SiO}_{2}$ ).

3 One of the possible reactions between $\mathrm{K}_{2} \mathrm{CO}_{3}$ and potassium silicates has been illustrated in

4 Figure 9. The interface between $\mathrm{K}_{2} \mathrm{CO}_{3}$ and the product layer probably has a relatively low local

$5 \mathrm{Si}: \mathrm{K}$ ratios. Thus, according to the thermodynamic calculations in Figure 2, the reaction rate at

6 the interface may be inhibited by the presence of $\mathrm{CO}_{2}$, resulting in the experimentally observed

7 lower reaction rate under $\mathrm{CO}_{2}$ atmospheres.

\section{$8 \quad 3.5$ Practical implication}

9 The investigated mechanism of the reaction between $\mathrm{K}_{2} \mathrm{CO}_{3}$ and $\mathrm{SiO}_{2}$ can contribute to the 10 overall understanding of agglomeration mechanisms in biomass-fired fluidized bed boilers.

11 Potassium carbonate may be generated from conversion of char bounded potassium, as indicated 12 by previous research $[12,20,21]$. At the typical fluidized bed boiler temperatures (around 850

$13{ }^{\circ} \mathrm{C}$ ), formed $\mathrm{K}_{2} \mathrm{CO}_{3}$ is typically present in form of aerosols. It can come into a contact with the 14 silica sand particles, thus initiating solid-solid state reaction that results in thee formation of a 15 molten potassium silicates product layer. The layer can further react with the attached $\mathrm{K}_{2} \mathrm{CO}_{3}$. As 16 a consequence, the thickness of the product layer will increase. At the same time, the formed 17 product layer is capable of dissolving $\mathrm{SiO}_{2}$, which will further increase the thickness of the 18 formed coating layer. As the layer thickness is increasing, the particle becomes stickier and they 19 will agglomerate when a critical thickness is achieved. This may cause bed defluidization.

\section{4. CONCLUSIONS}

22 Based on the results of this work, the following conclusions can be drawn for the reaction 23 between $\mathrm{K}_{2} \mathrm{CO}_{3}$ and silica sand:

1. Potassium carbonate can react with silica sand to release $\mathrm{CO}_{2}$ at temperatures well below the decomposition temperature of potassium carbonate. The reaction occurs in solid-solid phase with a high reaction rate at temperatures relevant to fluidized bed combustors $\left(>800^{\circ} \mathrm{C}\right)$.

2. The reaction rate increases with increasing temperature, but decreases with an increase of $\mathrm{CO}_{2}$ partial pressure. Mixing of the two solid reactants has a significant impact on the reaction rate, which is much higher for the well mixed particles than for the segregated particles due to enhanced contact between the solid particles. Moreover, the reaction rate is affected in a same way by the particle size of $\mathrm{K}_{2} \mathrm{CO}_{3}$, i.e. smaller particle size results in a higher reaction rate. 
3. Based on the SEM/EDS analyses of the samples, a plausible mechanism of the reaction is proposed. The reaction is initiated by surface reaction at the contact area between $\mathrm{K}_{2} \mathrm{CO}_{3}$ and silica sand, forming a molten homogeneous product layer. The product layer further reacts with $\mathrm{K}_{2} \mathrm{CO}_{3}$ and silica sand.

4. The results obtained in this work provide a basis for understanding of potassium carbonate induced agglomeration process in fluidized bed biomass combustion.

\section{ACKNOWLEDGMENT}

This project is funded by Innovation Fund Denmark (DANCNGAS), Sino-Danish Center for Education and Research, and Technical University of Denmark, which are gratefully acknowledged.

\section{REFERENCES}

[1] A.A. Khan, W. de Jong, P.J. Jansens, H. Spliethoff, Biomass combustion in fluidized bed boilers: Potential problems and remedies, Fuel Process. Technol. 90 (2009) 21-50.

[2] A. Grimm, N. Skoglund, D. Bostrom, M. Ohman, Bed Agglomeration Characteristics in Fluidized Quartz Bed Combustion of Phosphorus-Rich Biomass Fuels, Energy \& Fuels. 25 (2011) 937-947.

[3] M. Bartels, J. Nijenhuis, J. Lensselink, M. Siedlecki, W. de Jong, F. Kapteijn, J.R. van Ommen, Detecting and Counteracting Agglomeration in Fluidized Bed Biomass Combustion, Energy \& Fuels. 23 (2009) 157-169.

[4] S. van Loo, J. Koppejan, IEA Bioenergy. Task 32: Biomass Combustion and Co-Firing., Handbook of biomass combustion and Co-firing, Twente University Press, 2002.

[5] B. Gatternig, J. Karl, Investigations on the Mechanisms of Ash-Induced Agglomeration in Fluidized-Bed Combustion of Biomass, Energy \& Fuels. 29 (2016) 931-941.

[6] A.-L. Elled, L.-E. Åmand, B.-M. Steenari, Composition of agglomerates in fluidized bed reactors for thermochemical conversion of biomass and waste fuels: Experimental data in comparison with predictions by a thermodynamic equilibrium model, Fuel. 111 (2013) 696-708.

[7] L.H. Nuutinen, M.S. Tiainen, M.E. Virtanen, S.H. Enestam, R.S. Laitinen, Coating Layers on Bed Particles during Biomass Fuel Combustion in Fluidized-Bed Boilers, Energy \& Fuels. 18 (2004) 127-139.

[8] W. Lin, K. Dam-Johansen, F. Frandsen, Agglomeration in bio-fuel fired fluidized bed combustors, Chem. Eng. J. 96 (2003) 171-185. 
[9] F. Scala, R. Chirone, An SEM/EDX study of bed agglomerates formed during fluidized bed combustion of three biomass fuels, Biomass and Bioenergy. 32 (2008) 252-266.

[10] E. Brus, M. Öhman, A. Nordin, Mechanisms of Bed Agglomeration during Fluidized-Bed Combustion of Biomass Fuels, Energy \& Fuels. 19 (2005) 825-832.

[11] J.N. Knudsen, P.A. Jensen, K. Dam-Johansen, Transformation and Release to the Gas Phase of Cl, K, and S during Combustion of Annual Biomass, Energy \& Fuels. 18 (2004) $1385-1399$.

[12] K. Umamaheswaran, V.S. Batra, Physico-chemical characterisation of Indian biomass ashes, Fuel. 87 (2008) 628-638.

[13] P. Thy, C. Yu, B.M. Jenkins, C.E. Lesher, Inorganic Composition and Environmental Impact of Biomass Feedstock, Energy \& Fuels. 27 (2013) 3969-3987.

[14] G. Wang, L. Shen, C. Sheng, Characterization of Biomass Ashes from Power Plants Firing Agricultural Residues, Energy \& Fuels. 26 (2012) 102-111.

[15] D. Boström, N. Skoglund, A. Grimm, C. Boman, M. Öhman, M. Broström, R. Backman, Ash Transformation Chemistry during Combustion of Biomass, 26 (2012) 85-93.

[16] R. Xiao, X. Chen, F. Wang, G. Yu, The physicochemical properties of different biomass ashes at different ashing temperature, Renew. Energy. 36 (2011) 244-249.

[17] B. Olanders, B.-M. Steenari, Characterization of ashes from wood and straw, Biomass and Bioenergy 8 (1995) 105-115.

[18] J.M. Johansen, J.G. Jakobsen, F.J. Frandsen, P. Glarborg, Release of K, Cl, and S during Pyrolysis and Combustion of High-Chlorine Biomass, Energy \& Fuels. 25 (2011) 49614971.

[19] X. Wei, U. Schnell, K.R.G. Hein, Behaviour of gaseous chlorine and alkali metals during biomass thermal utilisation, Fuel. 84 (2005) 841-848.

[20] H. Wu, M.S. Bashir, P.A. Jensen, B. Sander, P. Glarborg, Impact of coal fly ash addition on ash transformation and deposition in a full-scale wood suspension-firing boiler, Fuel. 113 (2013) 632-643.

[21] H. Zhao, Q. Song, X. Wu, Q. Yao, Study on the Transformation of Inherent Potassium during the Fast-Pyrolysis Process of Rice Straw, Energy \& Fuels. 29 (2015) 6404-6411.

[22] C. Chen, Z. Luo, Y. Chunjiang, T. Wang, H. Zhang, Transformation behavior of potassium during pyrolysis of biomass, RSC Anvances. 7 (2017) 31319-31326.

[23] B.-J. Skrifvars, P. Yrjas, J. Kinni, P. Siefen, M. Hupa, The Fouling Behavior of Rice Husk Ash in Fluidized-Bed Combustion. 1. Fuel Characteristics, Energy and Fuels. 19 (2005) $1503-1511$.

[24] P. Piotrowska, M. Zevenhoven, K. Davidsson, M. Hupa, L.-E. Åmand, V. Barišić, E. Coda Zabetta, Fate of Alkali Metals and Phosphorus of Rapeseed Cake in Circulating 
Fluidized Bed Boiler Part 1: Cocombustion with Wood, Energy and Fuels. 24 (2010) 333345.

3 [25] C. Sevonius, P. Yrjas, M. Hupa, Defluidization of a quartz bed - Laboratory experiments with potassium salts., Fuel. 127 (2013).

[26] V. Narayan, P.A. Jensen, U.B. Henriksen, P. Glarborg, W. Lin, R.G. Nielsen, Defluidization in fluidized bed gasifiers using high-alkali content fuels, Biomass and Bioenergy. 91 (2016) 160-174.

[27] T. Ma, C. Fan, L. Hao, S. Li, W. Song, W. Lin, Biomass-Ash-Induced Agglomeration in a Fluidized Bed. Part 1: Experimental Study on the Effects of a Gas Atmosphere, Energy \& Fuels. 30 (2016) 6395-6404.

[28] S. Arvelakis, P.A. Jensen, K. Dam-Johansen, Simultaneous Thermal Analysis (STA) on Ash from High-Alkali Biomass, Energy \& Fuels. 18 (2004) 1066-1076.

[29] R.C.E. Modolo, L.A.C. Tarelho, E.R. Teixeira, V.M. Ferreira, J.A. Labrincha, Treatment and use of bottom bed waste in biomass fluidized bed combustors, Fuel Process. Technol. 125 (2014) 170-181.

16 [30] A.M. Alper, Phase diagrams in advanced ceramics, Academic Press, 1995.

[31] G. Gibsont, R. Ward, Reactions in solid state: reaction between sodium carbonate and quartz, J. Am. Ceram. Soc. 26 (1943) 239-246.

[32] J. Grynberg, E. Gouillart, M.-H. Chopinet, M.J. Toplis, Importance of the Atmosphere on the Mechanisms and Kinetics of Reactions Between Silica and Solid Sodium Carbonate, 


\section{FIGURES}

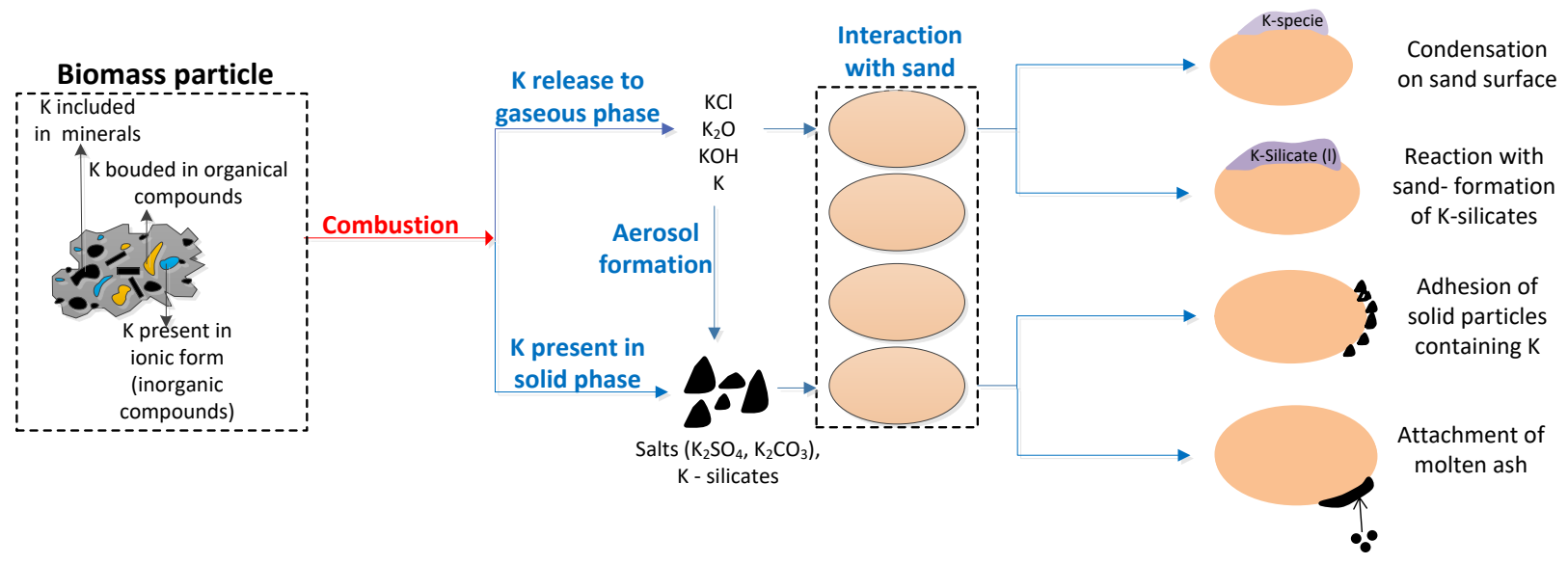

3

4

5

6

7

8

9

Figure 1: Interaction between potassium species formed during biomass combustion and bed material. 
Pure $\mathrm{N}_{2}$
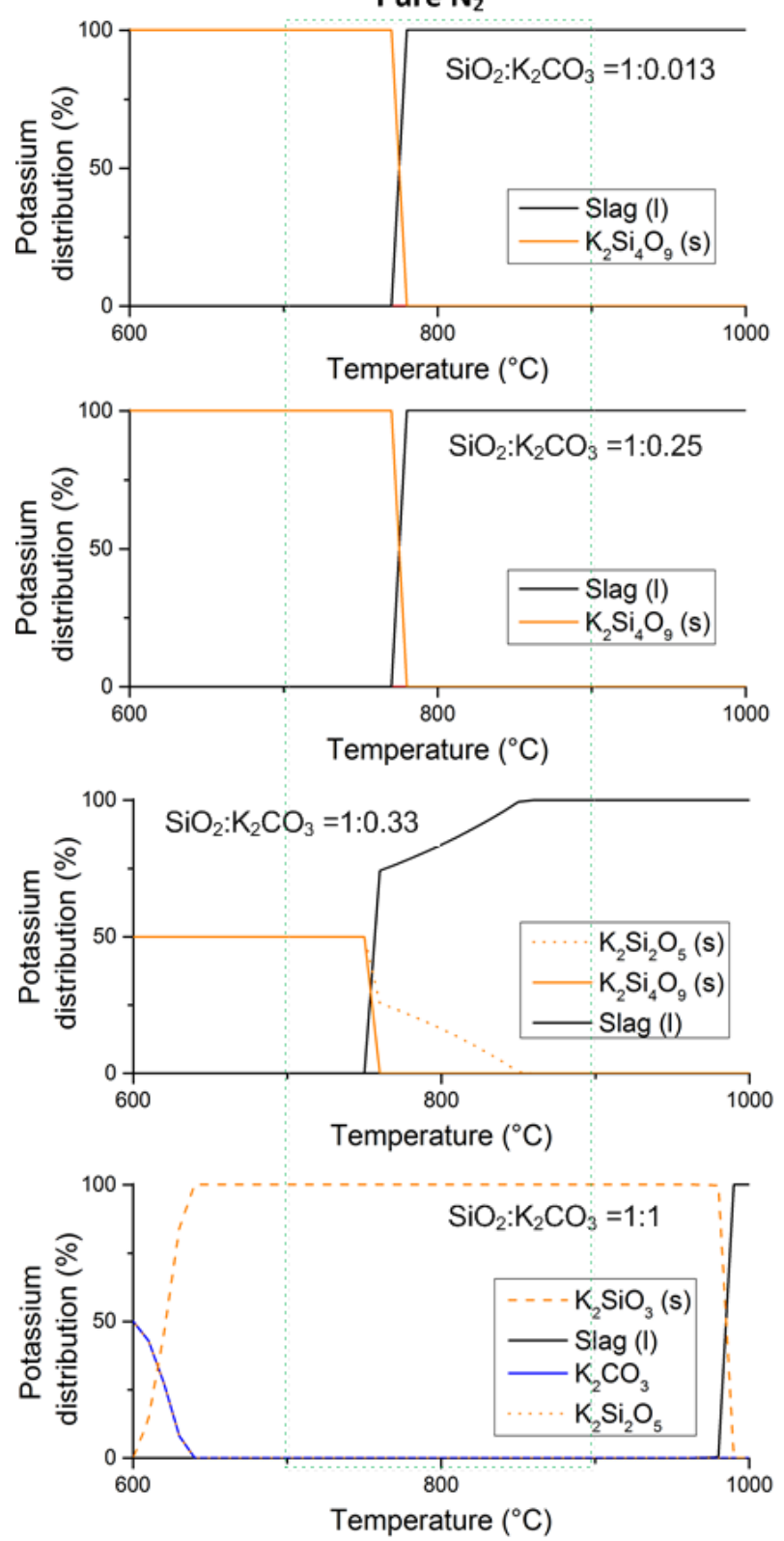

Pure $\mathrm{CO}_{2}$
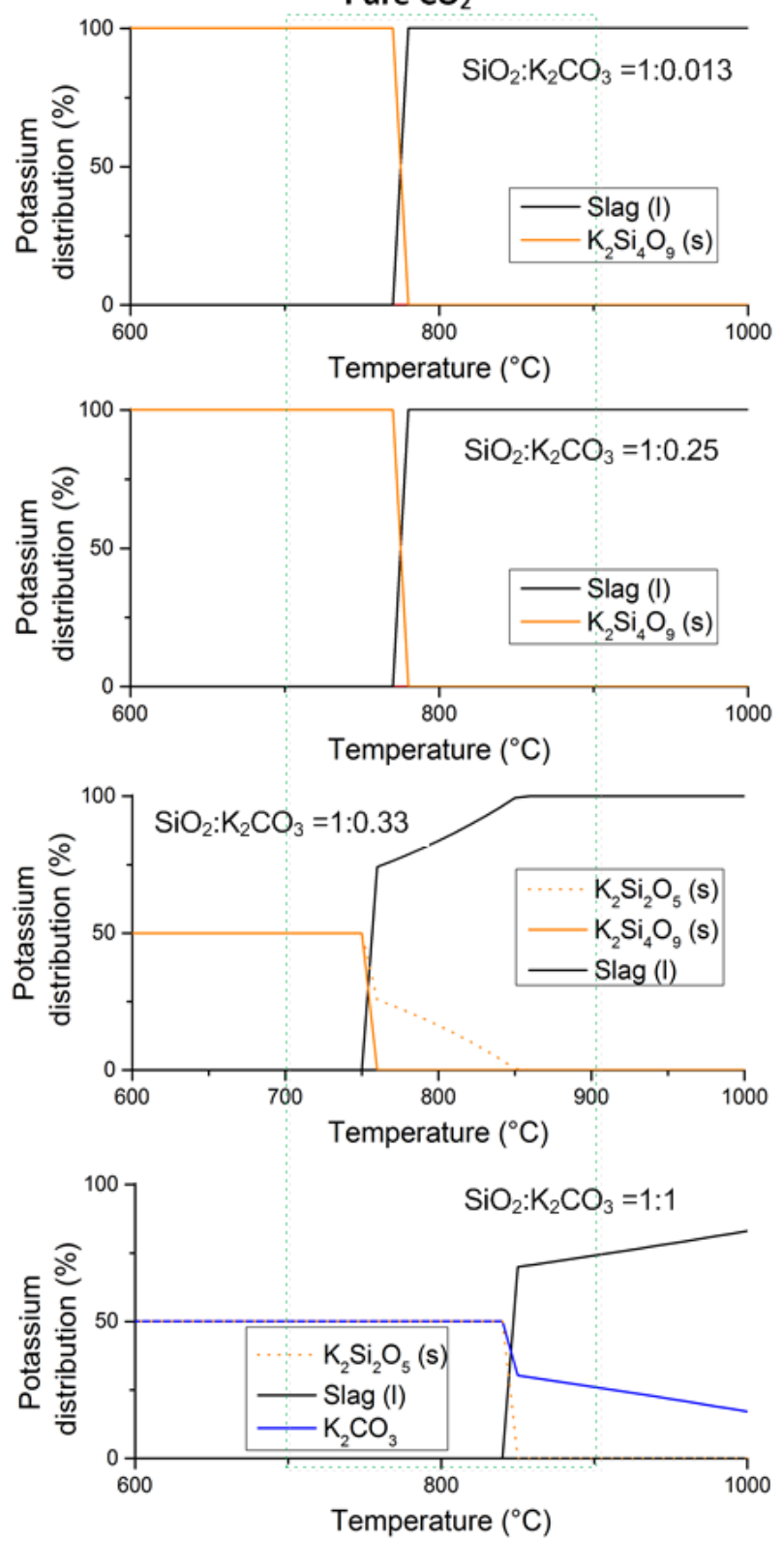

Figure 2: Thermodynamic equilibrium calculation for different $\mathrm{SiO}_{2}: \mathrm{K}_{2} \mathrm{CO}_{3}$ molar ratios under different atmosphere 


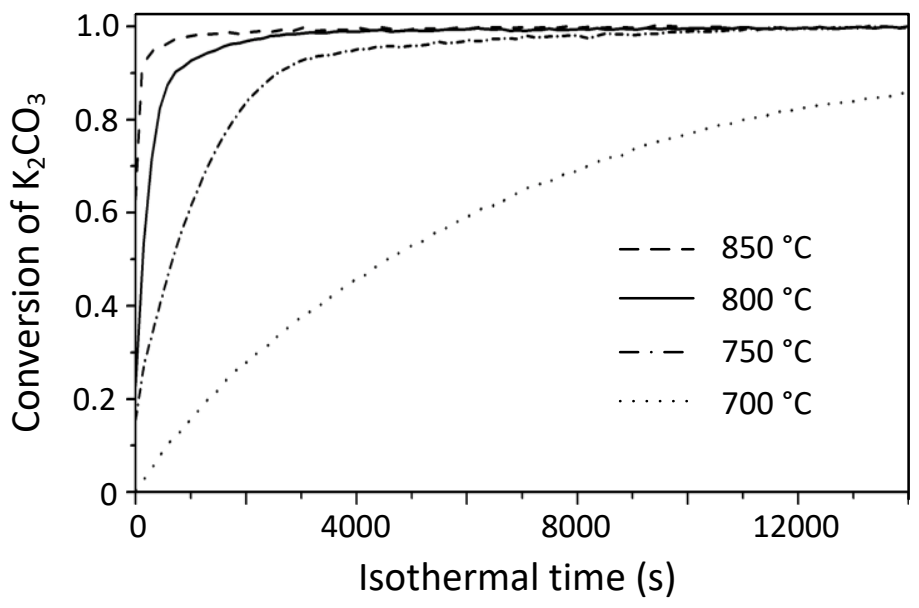

2 Figure 3: $\mathrm{K}_{2} \mathrm{CO}_{3}$ conversion rates at different temperatures. Pure $\mathrm{N}_{2}$ environment; $\mathrm{SiO}_{2}: \mathrm{K}_{2} \mathrm{CO}_{3}$ molar ratio = 1:0.013; 3 well mixed mixtures; powder $\mathrm{K}_{2} \mathrm{CO}_{3}$; total residence time $4 \mathrm{~h}$. 


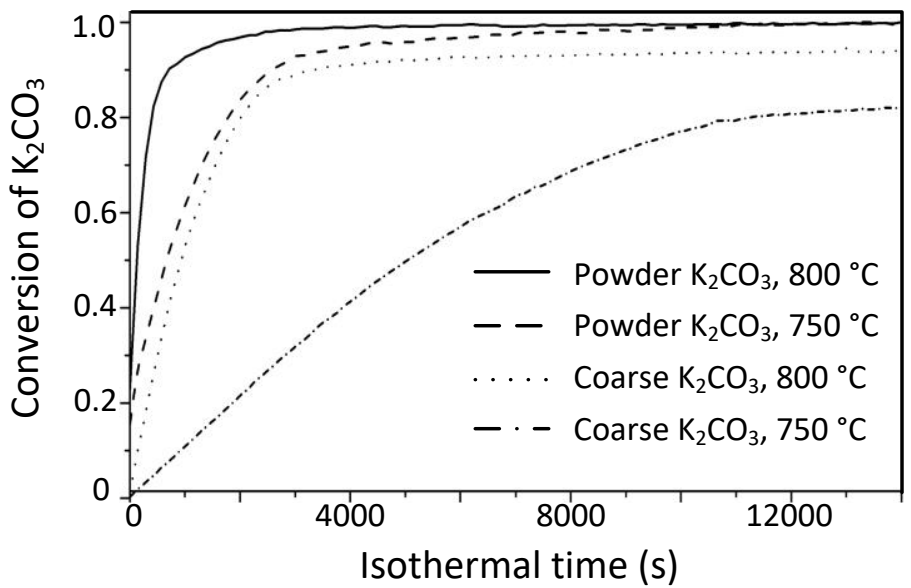

2 Figure 4: $\mathrm{K}_{2} \mathrm{CO}_{3}$ conversion rates for different sizes of $\mathrm{K}_{2} \mathrm{CO}_{3}$. Pure $\mathrm{N}_{2}$ environment; $\mathrm{SiO}_{2}: \mathrm{K}_{2} \mathrm{CO}_{3}$ molar ratio = 1:0.013; 3 well mixed mixtures; total residence time $4 \mathrm{~h}$. 


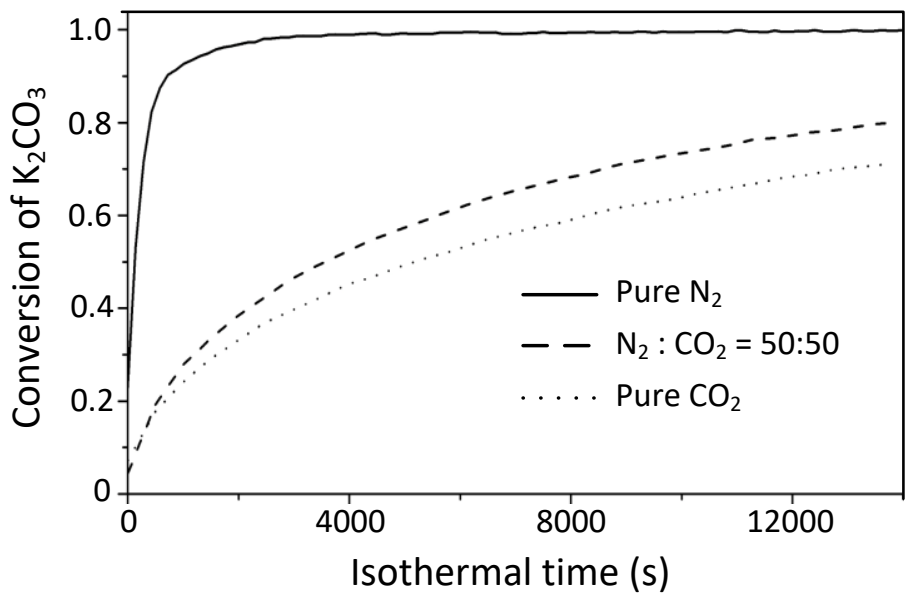

2 Figure 5: $\mathrm{K}_{2} \mathrm{CO}_{3}$ conversion rates under different gas atmospheres. $\mathrm{T}=800{ }^{\circ} \mathrm{C}, \mathrm{SiO}_{2}: \mathrm{K}_{2} \mathrm{CO}_{3}$ molar ratio $=1: 0.013$; well 3 mixed mixtures; powder $\mathrm{K}_{2} \mathrm{CO}_{3}$; total residence time $4 \mathrm{~h}$. 


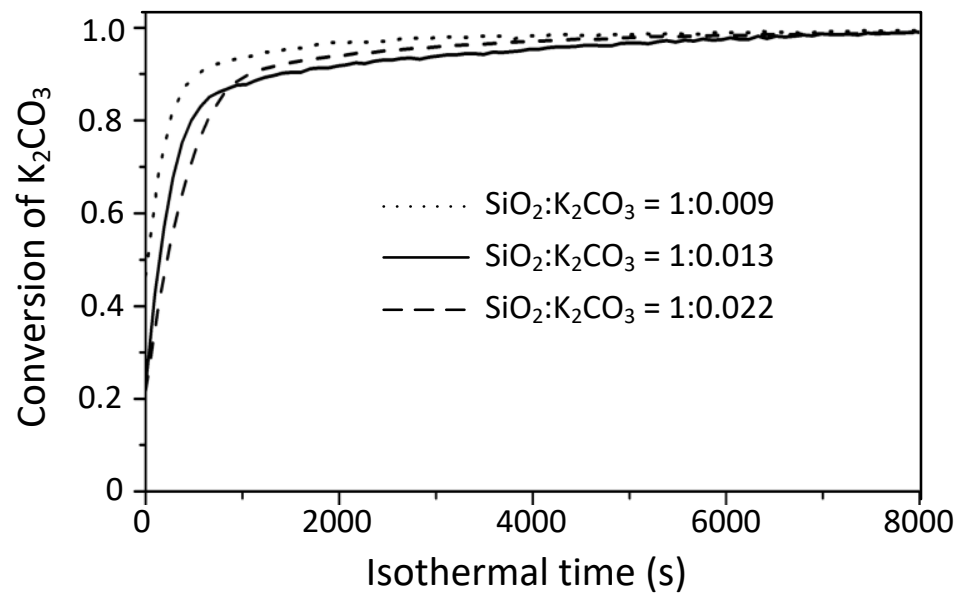

2 Figure 6: $\mathrm{K}_{2} \mathrm{CO}_{3}$ conversion rates for $\mathrm{K}_{2} \mathrm{CO}_{3}$ :sand mixtures with different molar ratio. $\mathrm{T}=800{ }^{\circ} \mathrm{C}$, Pure $\mathrm{N}_{2}$; well mixed 3 mixtures; powder $\mathrm{K}_{2} \mathrm{CO}_{3}$; total residence time 4h. $\left(\mathrm{SiO}_{2}: \mathrm{K}_{2} \mathrm{CO}_{3}=1: 0.009 \mathrm{~mol} / \mathrm{mol}=100: 2\right.$ wt. $/ \mathrm{wt} ; \mathrm{SiO}_{2}: \mathrm{K}_{2} \mathrm{CO}_{3}=1: 0.013$ $4 \mathrm{~mol} / \mathrm{mol}=100: 3 \mathrm{wt} . / \mathrm{wt} . ; \mathrm{SiO}_{2}: \mathrm{K}_{2} \mathrm{CO}_{3}=1: 0.022 \mathrm{~mol} / \mathrm{mol}=100: 5 \mathrm{wt} . / \mathrm{wt}$.) 


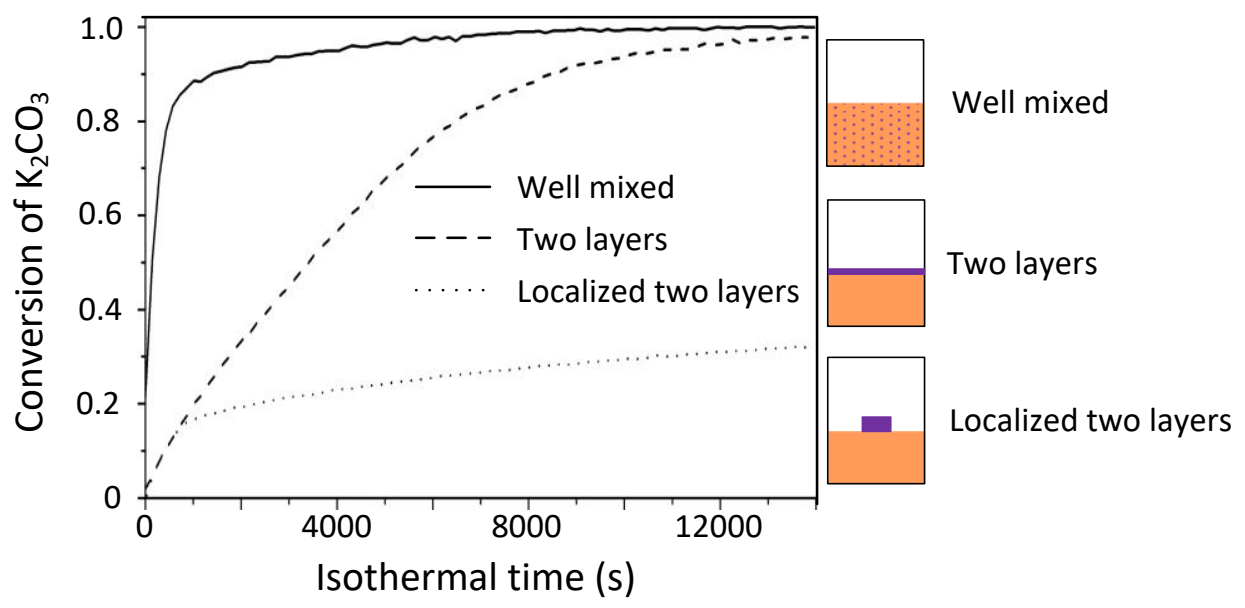

2 Figure 7: $\mathrm{K}_{2} \mathrm{CO}_{3}$ conversion rates for different mixtures. $\mathrm{T}=800{ }^{\circ} \mathrm{C} ;$ Pure $\mathrm{N}_{2} ; \mathrm{SiO}_{2}: \mathrm{K}_{2} \mathrm{CO}_{3}$ molar ratio $=1: 0.013 ;$ powder $3 \quad \mathrm{~K}_{2} \mathrm{CO}_{3}$; total residence time $4 \mathrm{~h}$. 


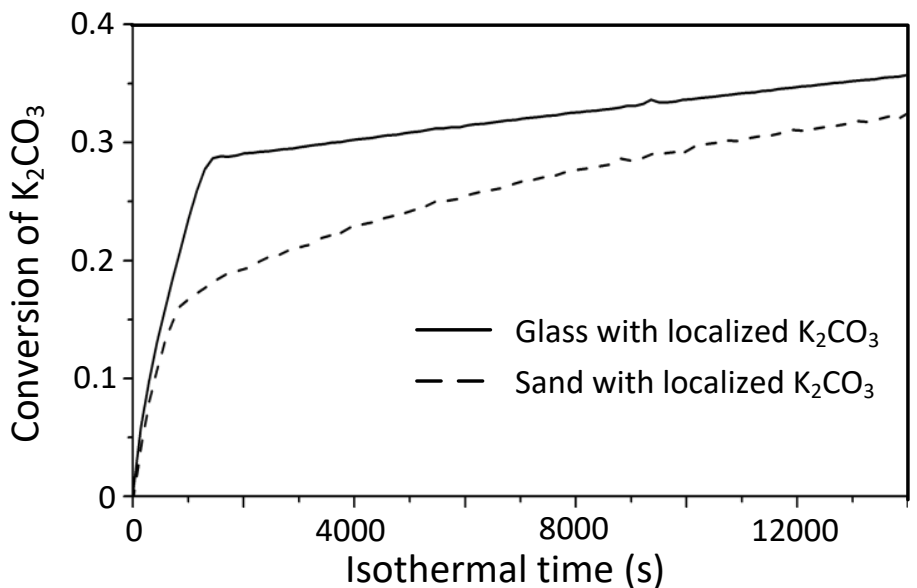

2 Figure 8: $\mathrm{K}_{2} \mathrm{CO}_{3}$ conversion rates rate for $\mathrm{SiO}_{2} / \mathrm{K}_{2} \mathrm{CO}_{3}$ and fused glass $/ \mathrm{K}_{2} \mathrm{CO}_{3}$ samples. $\mathrm{T}=800{ }^{\circ} \mathrm{C}$; Pure $\mathrm{N}_{2}$; powder $3 \quad \mathrm{~K}_{2} \mathrm{CO}_{3}$; total residence time $4 \mathrm{~h}$. 


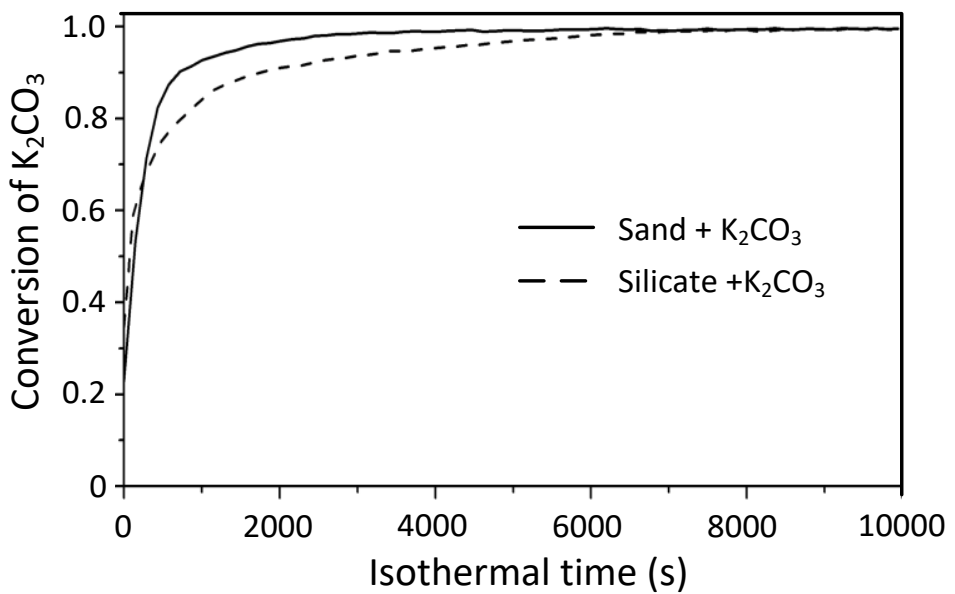

Figure 9: $\mathrm{K}_{2} \mathrm{CO}_{3}$ conversion rate of $\mathrm{SiO}_{2}: \mathrm{K}_{2} \mathrm{CO}_{3}$ and $\mathrm{K}_{2} \mathrm{Si}_{4} \mathrm{O}_{9}: \mathrm{K}_{2} \mathrm{CO}_{3}$ mixtures: $\mathrm{T}=800{ }^{\circ} \mathrm{C}$; Pure $\mathrm{N}_{2}$; powder $\mathrm{K}_{2} \mathrm{CO}_{3}$; total residence time $4 \mathrm{~h}$. 


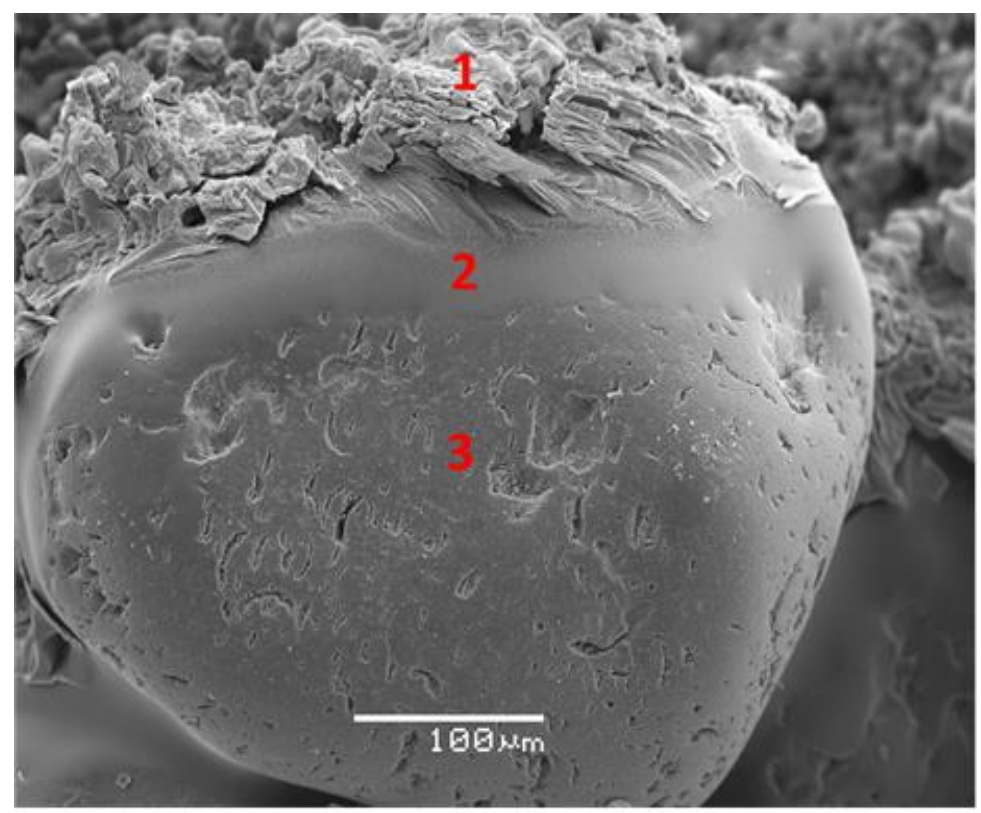

Elemental composition ( $\mathrm{mol} \%$ )

\begin{tabular}{|c|c|c|c|c|}
\hline Spot & $\mathrm{K}$ & $\mathrm{O}$ & $\mathrm{Si}$ & Si:K ratio \\
\hline 1 & 0.17 & 0.83 & 0 & 0 \\
\hline 2 & 0.12 & 0.67 & 0.21 & 1.85 \\
\hline 3 & 0 & 0.52 & 0.48 & - \\
\hline
\end{tabular}

2 Figure 10: $\mathrm{SEM}-\mathrm{EDX}$ analysis of a representative reaction product: $0.22 \mathrm{~K}_{2} \mathrm{CO}_{3}$ conversion; $\mathrm{SiO}_{2}: \mathrm{K}_{2} \mathrm{CO}_{3}$ molar ratio = $31: 0.013$; $\mathrm{T}=800{ }^{\circ} \mathrm{C}$; pure $\mathrm{CO}_{2}$ atmosphere; segregated mixture; powder form of $\mathrm{K}_{2} \mathrm{CO}_{3}$; isothermal reaction time $4 \mathrm{~h}$. 


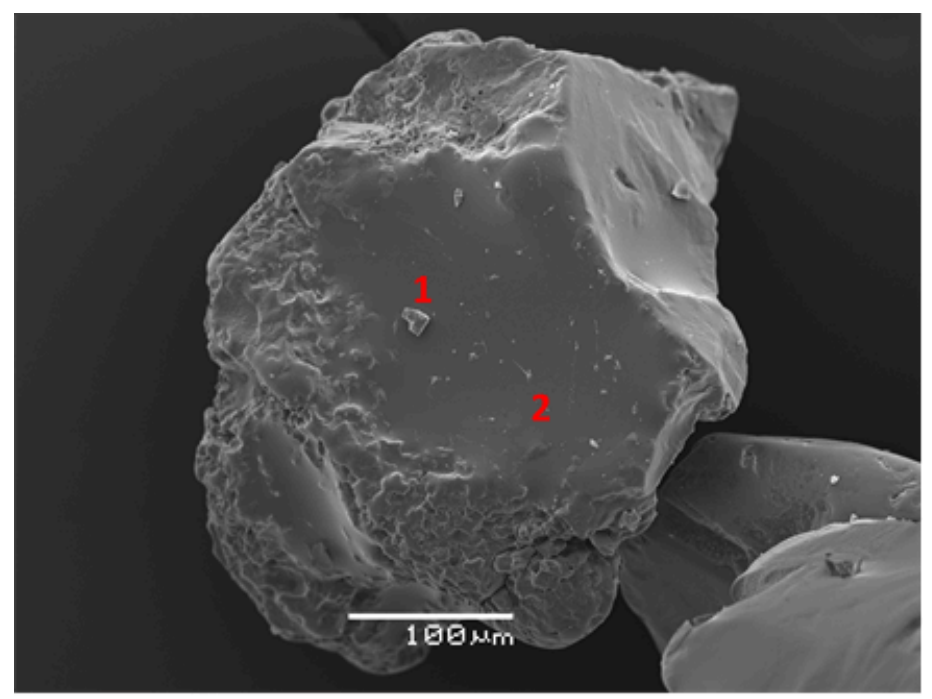

Elemental composition ( $\mathrm{mol} \%$ )

\begin{tabular}{|c|c|c|c|c|}
\hline Spot & $\mathrm{K}$ & $\mathrm{O}$ & $\mathrm{Si}$ & Si:K ratio \\
\hline 1 & 0.11 & 0.55 & 0.34 & 2.97 \\
\hline 2 & 0.10 & 0.60 & 0.30 & 3.08 \\
\hline
\end{tabular}

2 Figure 11: SEM-EDX analysis of a silica sand grain covered by formed product layer: full $\mathrm{K}_{2} \mathrm{CO}_{3}$ conversion $3 \quad \mathrm{SiO}_{2}: \mathrm{K}_{2} \mathrm{CO}_{3}$ molar ratio = 1:0.013; $\mathrm{T}=800{ }^{\circ} \mathrm{C}$; pure $\mathrm{N}_{2}$ atmosphere; well mixed sample; powder form of $\mathrm{K}_{2} \mathrm{CO}_{3}$; 4 isothermal reaction time $4 \mathrm{~h}$. 

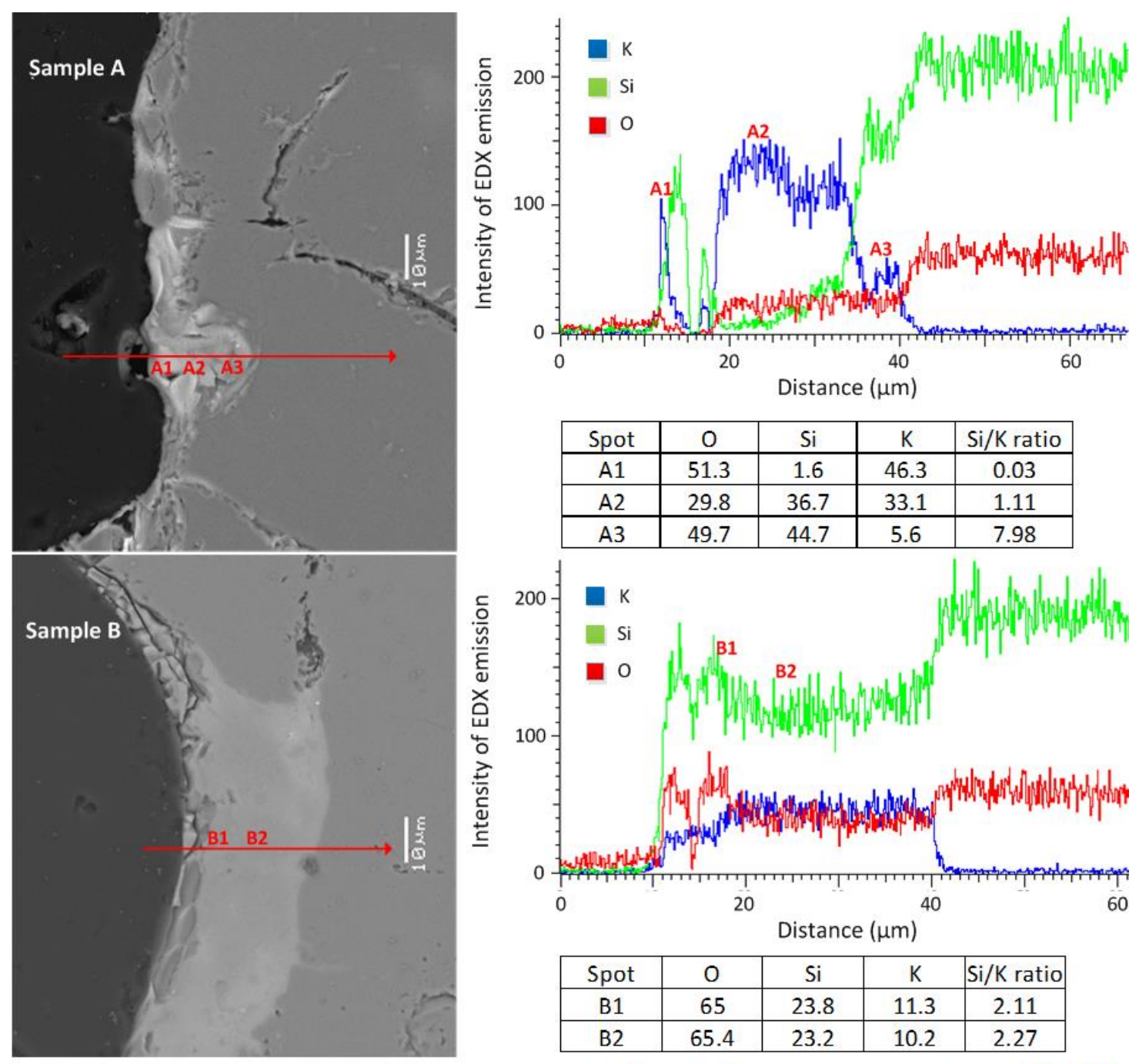

\begin{tabular}{|c|c|c|c|c|}
\hline Spot & O & Si & K & Si/K ratio \\
\hline B1 & 65 & 23.8 & 11.3 & 2.11 \\
\hline B2 & 65.4 & 23.2 & 10.2 & 2.27 \\
\hline
\end{tabular}
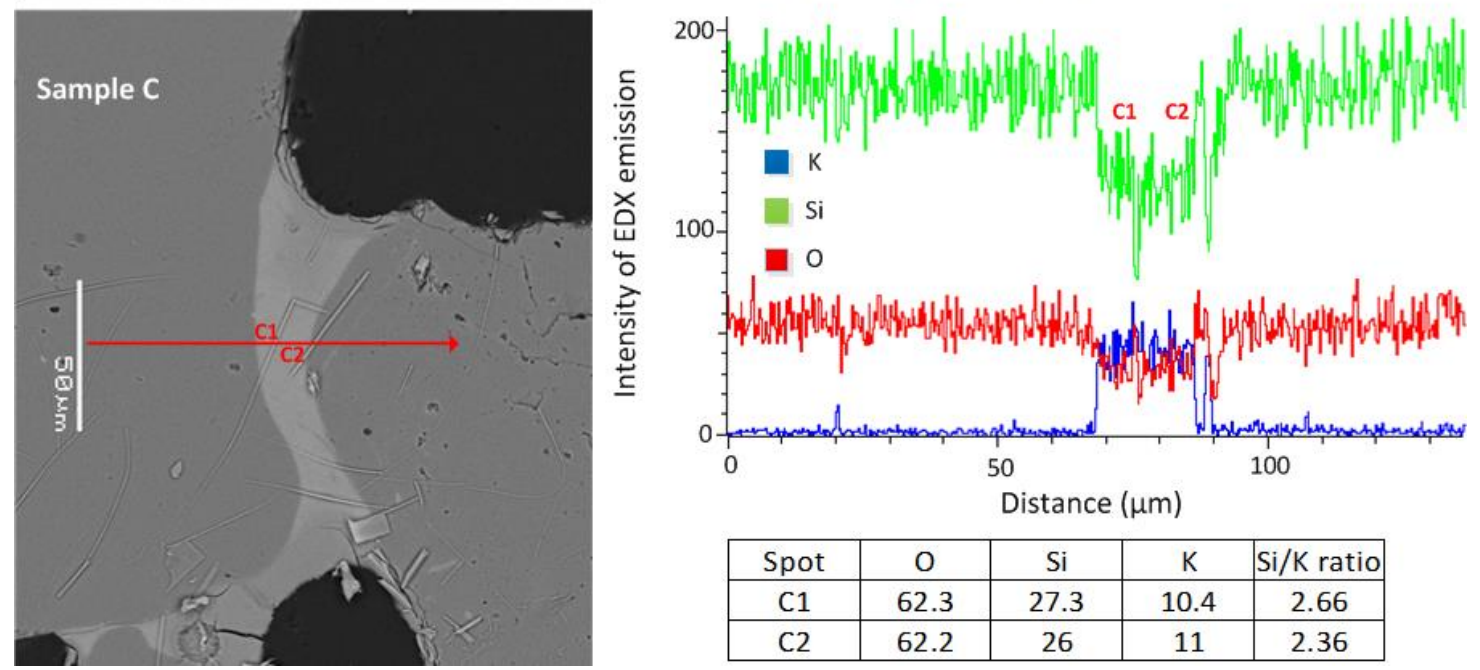

\begin{tabular}{|c|c|c|c|c|}
\hline Spot & $\mathrm{O}$ & $\mathrm{Si}$ & $\mathrm{K}$ & $\mathrm{Si} / \mathrm{K}$ ratio \\
\hline C1 & 62.3 & 27.3 & 10.4 & 2.66 \\
\hline C2 & 62.2 & 26 & 11 & 2.36 \\
\hline
\end{tabular}

Figure 12: SEM-EDX analysis of imbedded samples. Sample A: $\mathrm{K}_{2} \mathrm{CO}_{3}$ conversion 0.15 ; $\mathrm{SiO}_{2}: \mathrm{K}_{2} \mathrm{CO}_{3} \mathrm{molar}$ ratio = 1:0.013; $\mathrm{T}=800{ }^{\circ} \mathrm{C}$; pure $\mathrm{CO}_{2}$ atmosphere; residence time $10 \mathrm{~min}$. Sample $\mathrm{B}: \mathrm{K}_{2} \mathrm{CO}_{3}$ conversion $\mathrm{O.55}_{5} \mathrm{SiO}_{2}: \mathrm{K}_{2} \mathrm{CO}_{3} \mathrm{molar}$ ratio $=1: 0.013 ; \mathrm{T}=800{ }^{\circ} \mathrm{C}$; pure $\mathrm{CO}_{2}$ atmosphere; residence time $2 \mathrm{~h}$. Sample $\mathrm{C}: \mathrm{K}_{2} \mathrm{CO}_{3}$ conversion $\mathrm{O.99}_{2} \mathrm{SiO}_{2}: \mathrm{K}_{2} \mathrm{CO}_{3}$ molar ratio $=1: 0.013 ; T=800{ }^{\circ} \mathrm{C}$; pure $\mathrm{N}_{2}$ atmosphere; residence time $4 \mathrm{~h}$. 


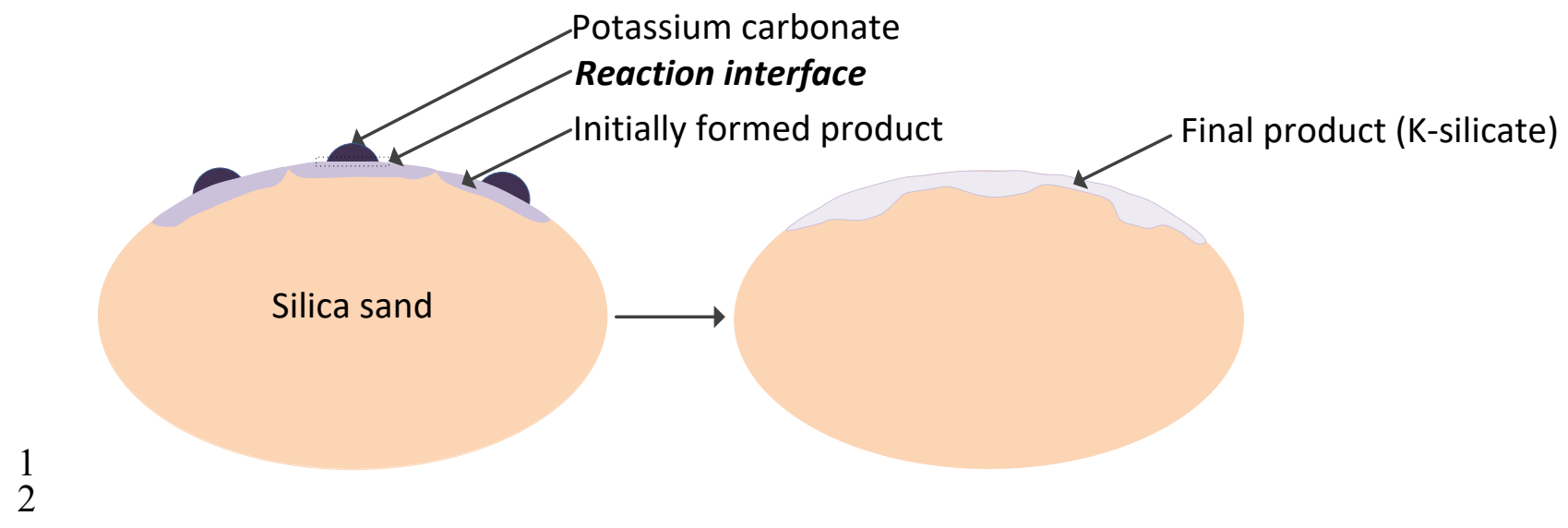

3 Figure 13: Schematic representation of the reaction mechanisms between $\mathrm{K}_{2} \mathrm{CO}_{3}$ and silica sand 4 